\title{
KAJIAN SANAD, MATAN DAN SYARAH HADIS TENTANG HUKUM BARANG TEMUAN
}

\author{
Sampara Palili \\ STIT Sunan Giri Bima \\ Email: syampara2511@gmail.com
}

\begin{abstract}
This article examines the sanad, matan and shari'ah traditions about the law of found items. The method used is library research using a descriptive normative approach that emphasizes the analysis of data sources found. The hadith on the found law was narrated by 1) al-Bukhari in his Sahih 2) Muslims in his Sahih, 3) al-Tirmidhi in his Sunan, 4) Abu Dawud in his Sunan 5) Ibn Majah in his Sunan 6) Malik in al-Muatha 7) Ahmad bin Hanbal in his Musnad. The results of the study found that if someone found an item, he should not dare to take it unless he knew that he could be trusted in guarding it and was able to announce it until he found the owner. Anyone who feels that he cannot be trusted with the goods, then he may not take it. If he takes it, then he is similar to someone who seizes the property of others. Because, he took other people's property from the side that he was not allowed to take it. Also because by taking it at that time, it means that there is an act of wasting someone else's property.
\end{abstract}

Keywords: Study of Hadith, Law of Findings

\begin{abstract}
ABSTRAK
Artikel ini mengkaji sanad, matan dan syarah hadis tentang hukum barang temuan. Adapun metode yang digukan adalah library researc dengan menggunakan pendekatan normatif deskriptif yang menekankan pada analisis sumber-sumber data yang ditemukan. Hadis tentang hukum barang temuan diriwayatkan oleh 1) al-Bukhari dalam Shahih-nya 2) Muslim dalam Shahihnya, 3) al-Tirmidzi dalam Sunan-nya, 4) Abu Dawud dalam Sunannya 5) Ibnu Majah dalam Sunan-nya 6) Malik dalam al-Muatha 7) Ahmad bin Hanbal dalam Musnad-nya. Hasil penelitian memberikan temuan jika seseorang menemukan barang, janganlah dia berani untuk mengambilnya kecuali jika dia mengetahui bahwa dirinya bisa amanah dalam menjaganya dan mampu untuk mengumumkannya sampai dia menemukan pemiliknya. Barangsiapa yang merasa bahwa dirinya tidak bisa amanah terhadap barang tersebut, maka dia tidak boleh mengambilnya. Jika dia mengambilnya, maka dia serupa dengan orang yang merampas harta orang lain. Sebab, dia mengambil harta orang lain dari sisi yang dia tidak diperbolehkan untuk mengambilnya. Juga karena dengan mengambilnya ketika itu, berarti ada perbuatan menyia-nyiakan harta orang lain.
\end{abstract}

\section{Kata Kunci: Kajian Hadis, Hukum Barang Temuan}




\section{PENDAHULUAN}

Penemuan barang dalam kajian keislaman di kelompokkan dengan 2 istilah yaitu alLuqathah dan ad-Dhallah. Al-Luqathah biasa dimaknai sebagai semua barang yang terjaga, yang tersia-sia, dan tidak diketahui pemiliknya dalam artian (barang yang hilang/tercecer atau berpisah dengan pemilik sesungguhnya karena suatu hal), umumnya istilah ini berlaku untuk barang yang bukan hewan. Adapun hewan disebut ad-dhallah adalah hewan atau ternak yang ditemukan dari suatu tempat yang tidak di ketahui pemiliknya. ${ }^{1}$

Hukum mengambil barang temuan tersebuh dibagi menjadi 3 yaitu disunahkan, diwajibkan dan diharamkan. Apabila barang itu ditemukan di tempat yang tidak aman untuk barang temuan tersebut, maka wajib diambil. Namun, apabila si penu barang mengetahui bahwa dirinya mempunyai sifat ketamakan ketika mengambil barang tersebut, maka haram baginya utuk mengambil barang tersebut. Dasar masalah ini adalah hadis yang diriwayatkan dari Zaid bin Khalid al Juhani ra. berkata Sesungguhnya Nabi Saw ditanya perihal barang temuan ; emas dan perak ? Nabi menjawab, ketahuilah olehmu talinya (ikatannya), bungkusnya kemudian umumkan selama setahun, jika dalam masa itu tidak ada yang mengakuinya,bolehlah barang temuan itu anda belanjakan,sebagai amanat ditanganmu, jika kemudian pemiliknya datang memintanya, serahkanlah (ganti barangnya/harganya) ......... (HR. Bukhori dan Muslim) ${ }^{2}$

Perlu dipahami bahwa hukum di Atas tidak berlaku bagi barang temuan (al-Luqathah) yang ditemukan di Makkah. Bila ada barang temuan tertinggal di Tanah Suci, maka diharamkan mengambilnya kecuali untuk diumumkan. Rasulullah SAW bersabda: "Tidak boleh memungut barang temuan didaerah ini (maksudnya Makkah) kecuali bagi orang yang akan memperkenalkannya." Wajib hukumnya bagi orang yang menemukan barang temuan untuk mengamati tanda-tanda yang membedakannya dengan barang lainnya, baik itu berbentuk tempatnya atau ikatannya, demikian pula yang berhubungan dengan jenis dan ukurannya. Bagi yang menemukannya juga berkewajiban memelihara barang temuan itu seperti memelihara barangnya sendiri. Dalam hal ini, tidak ada bedanya untuk barang yang remeh atau barang penting. Barang tersebut berada padanya sebagai barang wadi'ah (titipan). Ia tidak berkewajiban menjamin jika terjadi kecelakaan kecuali dengan sengaja. Kemudian setelah itu, ia berkewajiban mengumumkannya kepada masyarakat dengan berbagai cara: di pasar dan di tempat-tempat lain yang diduga kuat pemiliknya ada di tempat itu.

\footnotetext{
${ }^{1}$ Sayyid Sabiq, Fiqih Sunnah 13, Pent.: Kamaluddin A. Marzuki (Bandung :PT. Al Ma’arif, 1987),Cet. I, hal. 85

${ }^{2}$ Sulaiman Toha, Terjemahan Hadits Shahih Muslim, (Jakarta : Pustaka al Husna, 1991), Cet. III, hal.33
} 
Jika pemiliknya datang dan ia menyebutkan tanda-tanda dan ciri-ciri barang temuan tersebut dengan sempurna, maka si penemu dibolehkan menyerahkanya kepada orang tersebut, sekalipun tidak ada bukti nyata. Jika pemilik tidak datang, penemu berkewajiban mengumumkannya selama satu tahun. Setelah satu tahun tidak ada yang mengaku, maka halal baginya bersedekah dengan barang tersebut atau memanfaatkannya sendiri baik dia orang kaya maupun miskin. Dan dia tidak berkewajiban menjaminnya.

Dengan demikian untuk mengetahui terkait permasalahan hukum barang temuan maka diperlukan kajian mendalam dengan menampilkan takhrij matan dan syarah hadis terkait perihal tersebut, sehingga matan hadis tentang hukum barang temuan bisa dijadikan hujjah atau dalil dalam memberikan pemahaman kepada masyarakat.

\section{METODOLOGI PENELITIAN}

Jenis penelitian yang digunakan pada kajian ini adalah kepustakaan (Library Research). Peneliti menggunakan pendekatan normatif deskriptif yang menekankan pada analisis sumbersumber data yang ditemukan. studi kepustakaan merupakan segala usaha yang dilakukan oleh peneliti untuk menghimpun informasi yang relevan dengan topik atau masalah yang akan atau sedang diteliti. Informasi itu dapat diperoleh dari buku-buku ilmiah, laporan penelitian, karangan-karangan ilmiah, tesis, disertasi, peraturan-peraturan, ketetapan-ketetapan, buku tahunan, ensiklopedia, dan sumber-sumber tertulis lain baik tercetak maupun elektronik. ${ }^{3}$ Adapun Metode Analisis yang digunakan adalah content analysis (analisis isi) sebagaimana dikutip oleh Burhan Bungin mengatakan bahwa content analysis adalah suatu metodologi penelitian yang memanfaatkan seperangkat prosedur untuk menarik kesimpulan yang sahih dari sebuah buku atau dokumen. ${ }^{4}$

\section{Takhrij Hadis}

Periwayatan hadis dengan menyebutkan sanad nya mulai dari mukhrrij nya dan perawinya apabila sampai kepada Rasul saw maka hadis tersebut marfu' dan apabila hanya sampai kepada sahabat maka hadis tersebut maqtu'. 5 Dalam pelaksanaan takhrij ini penulis menggunakan metode takhrij bi al-lafazh dengan menggunakan petunjuk kamus hadis alMu'jam ditemukan potongan matan hadis اعْرِفْ terdapat dalam: 1) al-Bukhari dalam Shahih-nya Kitab al-Ilm bab al-Ghadhab fi al-Maw'izhah wa al-Ta'lim No. 89, 2) Muslim dalam Shahihnya Kitab al-al-Luqthqh No. 3247, 3248, 3249, 3250, 3) al-Tirmidzi dalam Sunan-nya Kitab al-

\footnotetext{
${ }^{3}$ Purwono,"Kajian Kepustakaan", dalam http://www.google.co.id (Diakses 20 Juli, 2017)

${ }^{4}$ Burhan Bungin, Metodologi Penelitian Kualitatif, (Jakarta: Raja Grafindo Persada, 2003), h. 173

${ }^{5}$ Nawir Yuslem, Ulumul Hadis , ( Jakarta, PT Mutiaraa Sumber Widya, 2001), h. 389
} 
Ahkam No. 1293, 4) Abudawud dalam Sunan-nya Kitab al-Luqthqh, N0. 1451, 1452, 1453, 5) Ibnu Majah dalam Sunan-nya Kitab al-Ahkam, No. 2495, 6) Ahmad bin Hanbal dalam Musnadnya Kitab Musnad al-Tsamiyyin, No. 16431, 20697, 7) Malik dalam al-Muatha' Kitab alIqdhiyah, No. $1248^{6}$

Bila ditelusri dengan lafazh وِكَاءَ ditemukan di dalam kitab al-Bukhari dalam Shahih-nya Kitab Luqathah, No hadis. 2199, 2150 dan kitab al-Thalaq No. hadis 4882, dan Ahmad bin Hanbal dalam Musnad-nya Kitab. Musnad al-Syamiyyin, No. 16422

Susunan redaksi hadis di atas adalah sebagai berikut:

a. al-Bukhari dalam Shahih-nya No. $89^{7}$

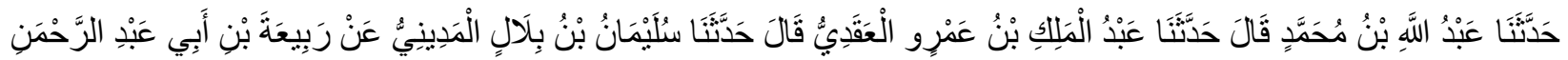

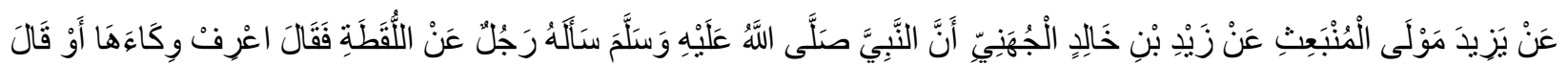

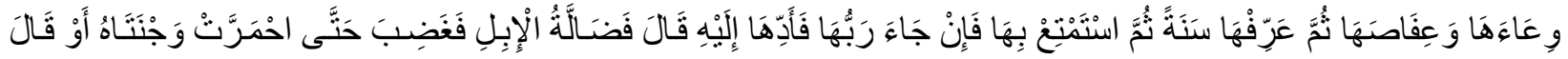

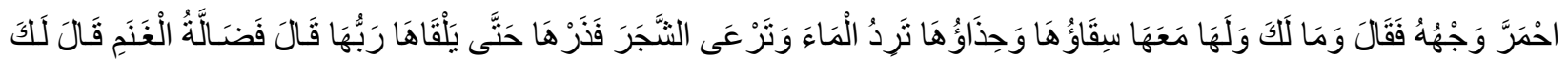

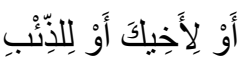

Telah menceritakan kepada kami Abdullah bin Muhammad berkata, Telah menceritakan kepada kami Abdul Malik bin 'Amru Al 'Aqadi berkata, Telah menceritakan kepada kami Sulaiman bin Bilal Al Madini dari Rabi'ah bin Abu Abdurrahman dari Yazid mantan budak Al Munba'its, dari Zaid bin Khalid Al Juhani bahwa Nabi shallallahu 'alaihi wasallam ditanya oleh seseorang tentang barang temuan, maka Nabi shallallahu 'alaihi wasallam bersabda: "Kenalilah tali pengikatnya, atau Beliau berkata; kantong dan tutupnya, kemudian umumkan selama satu tahun, setelah itu pergunakanlah. Jika datang pemiliknya maka berikanlah kepadanya". Orang itu bertanya: "Bagaimana dengan orang yang menemukan unta?" Maka Nabi shallallahu 'alaihi wasallam marah hingga nampak merah mukanya, lalu berkata: "apa urusanmu dengan unta itu, sedang dia selalu membawa air di perutnya, bersepatu sehingga dapat hilir mudik mencari minum dan makan rerumputan, maka biarkanlah dia hingga pemiliknya datang mengambilnya".

\footnotetext{
${ }^{6}$ Arnold John Wensinck, et al, Concordance et Indices De La Tradition Musulmane, diterjemahkan ke dalam Bahasa Arab oleh Muhammad Fu'ad 'Abd. al-Baqiy dengan judul al-Mu'jam al-Mufahras li Alfazh al-Hadis al-Nabawi, ( Leiden: E.J. Brill, 1967), h. 537

7al-Hafizh, Abi Abillah Muhammad bin Ismail, Shahih al-Bukhari, ( Semarang, Toha Putera, tt), h.25-26, 57
} 
Orang itu bertanya lagi tentang menemukan kambing, maka Beliau menjawab: "Itu untuk kamu atau saudaramu atau serigala".

No. Hadis 2199

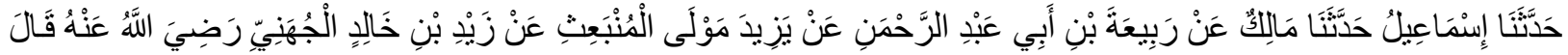

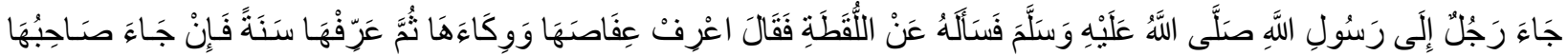

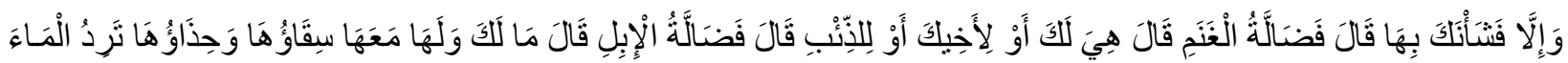

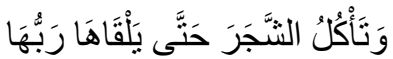

Telah menceritakan kepada kami Isma'il telah menceritakan kepada kami Malik dari Rabi'ah bin Abi 'Abdurrahman dari Yazid, maula Al Munba'its dari Zaid bin Khalid Al Juhaniy radliallahu 'anhu berkata; "Datang seorang laki-laki kepada Rasulullah shallallahu 'alaihi wasallam lalu bertanya kepada Beliau tentang barang temuan. Maka Beliau bersabda: "Kamu kenali tutup bungkus dan talinya kemudian umumkan selama satu tahun dan jika datang pemiliknya maka berikanlah namun bila tidak maka menjadi kewenanganmu dengan barang tersebut". Orang itu bertanya lagi tentang hukum bila menemukan kambing. Maka Beliau menjawab: "Itu untuk kamu atau saudaramu atau serigala". Lalu orang itu bertanya lagi tentang menemukan unta. Maka Beliau menjawab: "Bagaimana kamu ini, padahal unta itu mempunyai kantong air (yang terisi air) dan sepatunya sehingga dia bisa hilir mudik mencari air dan makan rerumputan hingga pemiliknya menemukannya".

No. 2250

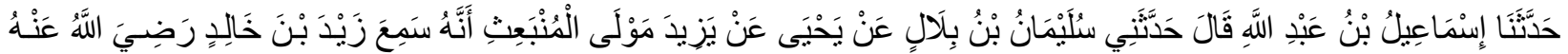

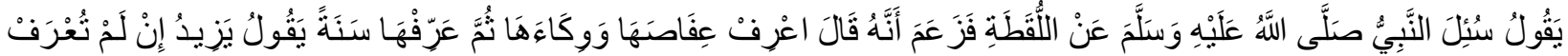

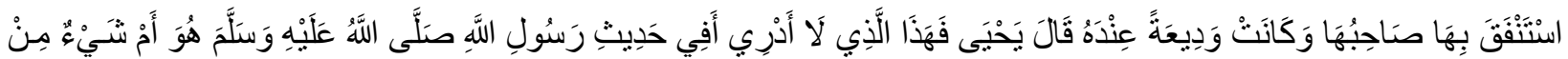

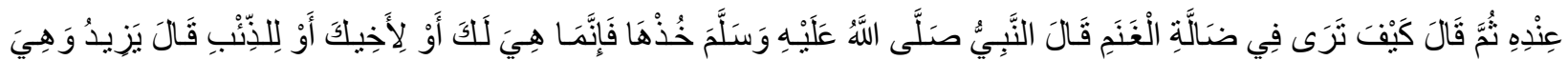

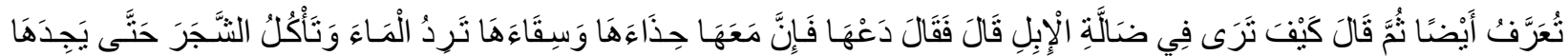

Telah menceritakan kepada kami Isma'il bin 'Abdullah berkata, telah menceritakan kepadaku Sulaiman bin Bilal dari Yahya dari Yazid, maula Al Munba'its bahwa dia mendengar Zaid bin Khalid radliallahu 'anhu berkata; "Nabi shallallahu 'alaihi wasallam ditanya tentang barang temuan". Maka Beliau bersabda: "Kamu kenali tutup bungkus dan talinya kemudian 
umumkan selama satu tahun". Yazid berkata: "Dan jika tidak ada yang mengakuinya maka dapat digunakan oleh penemunya karena itu berarti titipan Allah baginya". Yahya berkata: "Inilah yang aku tidak tahu apakah kalimat ini termasuk bagian dari hadits yang disabdakan Rasulullah shallallahu 'alaihi wasallam atau hanya perkataan dari Yazid. Kemudian orang itu bertanya lagi: "Bagaimana tentang menemukan kambing?" Nabi shallallahu 'alaihi wasallam menjawab: "Ambillah karena kambing itu untuk kamu atau saudaramu atau serigala". Yazid berkata: "Untuk kambing juga diumumkan dahulu". Kemudia orang itu bertanya lagi: "Bagaimana tentang menemukan unta. Yazid berkata; maka Beliau menjawab: "Biarkanlah unta itu, karena ia selalu nampak sepatunya dan perutnya (yang terisi air) sehingga ia bisa hilir mudik mencari air dan makan rerumputan hingga ditemukan oleh pemiliknya".

No. 4882

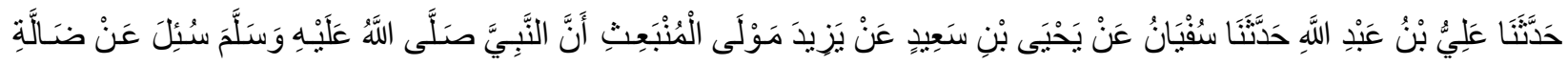

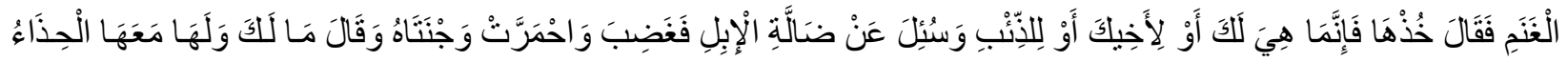

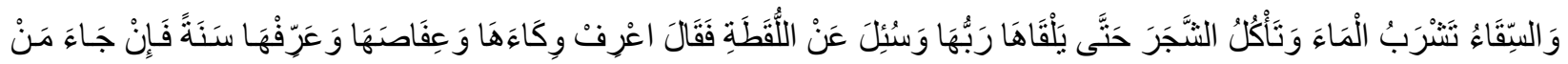

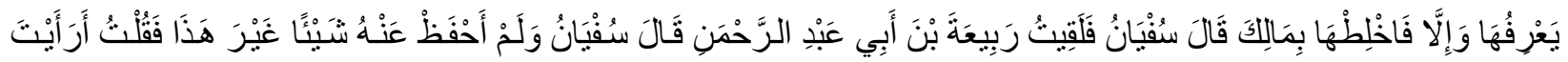

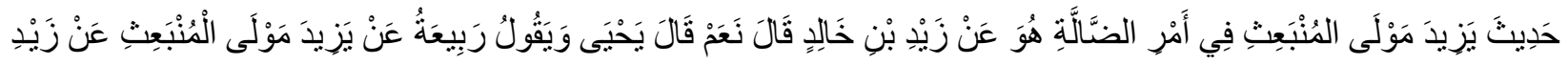

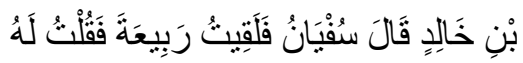

Telah menceritakan kepada kami Ali bin Abdullah Telah menceritakan kepada kami Sufyan dari Yahya bin Sa'id dari Yazid Maula Al Munba'its bahwasanya; Nabi shallallahu 'alaihi wasallam pernah ditanya mengenai kambing yang tersesat, maka beliau pun bersabda: "Sesungguhnya kambing itu adalah milikmu, atau milik saudaramu atau pun milik srigala." Kemudian beliau ditanya mengenai Unta yang hilang, maka wajah beliau memerah dan bersabda: "Kenapa kamu ini, bukankah Unta punya sepatu dan tempat minum yang ia pergunakan untuk mencari minum?. Dan bukankah ia juga dapat makan tumbuh-tumbuhan hingga ia menemui pemiliknya?" setelah itu, beliau ditanya tentang barang temuan. Maka beliau bersabda: "Tolong tandai tali dan tutupnya, dan umumkanlah barang itu selama satu tahun. Jika ada seseorang yang datang dan mengetahuinya berikanlah dan jika tidak, maka kamu boleh mencampurkannya dengan hartamu." Sufyan berkata; Lalu aku menemui Rabi'ah bin Abu Abdurrahman. Sufyan berkata; Aku tidak menghafal sesuatu pun darinya selain ini; Aku berkata, "Bagaimana pendapat Anda mengenai hadits Yazid Maula Al Munba'its terkait dengan barang yang hilang. Hadits itu dari Yazid bin Khalid?" Ia menjawab; Ya. Yahya berkata; Rabi'ah 
berkata; dari Yazid budak Al munba'its dari Zaid bin Khalid. Sufyan berkata; Maka aku pun menemui Rabi'ah dan bertanya padanya.

b. Muslim dalam Shahih-nya, No. $3247,3248,3249,3250^{8}$

No. 3247.

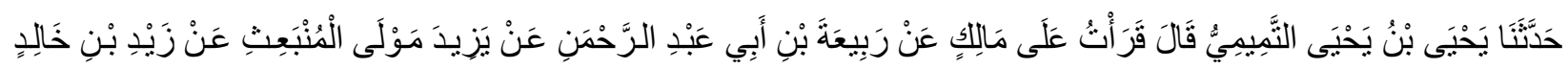

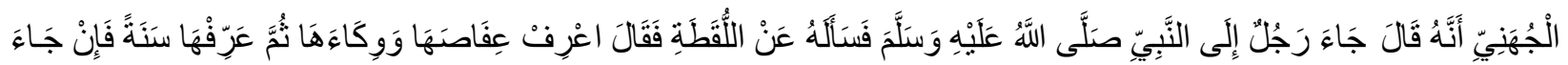

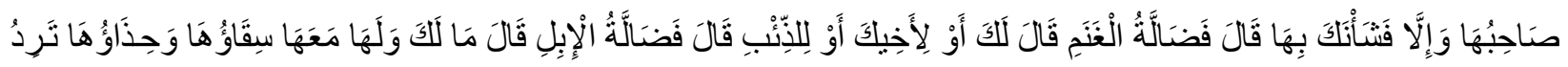

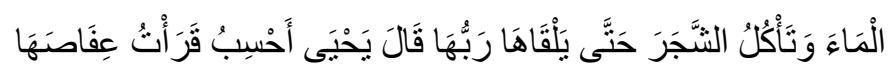

Telah menceritakan kepada kami Yahya bin Yahya At Tamimi dia berkata; aku bacakan di hadapan Malik; dari Rabi'ah bin Abu Abdurrahman dari Yazid bekas budak Al Munba'is, dari Zaid bin Khalid Al Juhani bahwa dia berkata, "Seseorang datang kepada Nabi shallallahu 'alaihi wasallam dan menanyakan mengenai barang temuan." Lalu beliau bersabda: "Kenalilah wadah dan talinya, setelah itu umumkanlah kepada khalayak ramai, apabila pemiliknya datang maka berikanlah barang tersebut kepadanya." Kemudian orang itu juga bertanya, "Wahai Rasulullah, bagaimana jika yang ditemukan adalah kambing?" Rasulullah shallallahu 'alaihi wasallam menjawab: "Mungkin ia dapat menjadi milikmu atau milik saudaramu atau bahkan menjadi milik serigala." Dia berkata, "Wahai Rasulullah, bagaimana jika yang ditemukan adalah unta?" beliau menjawab: "Apa urusanmu dengan unta yang hilang? Ia telah membawa sepatu (punya kaki) dan wadah airnya sendiri. Ia dapat mendatangi mata air dan makan dedaunan sampai ia bertemu pemiliknya." Yahya berkata, "Sepertinya aku membaca 'iffashaha (wadahnya)."

No 3248

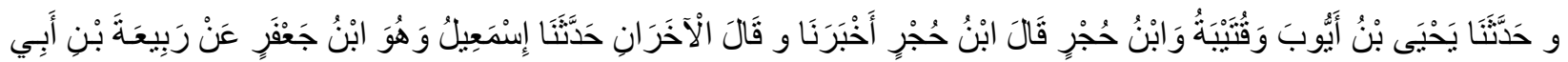

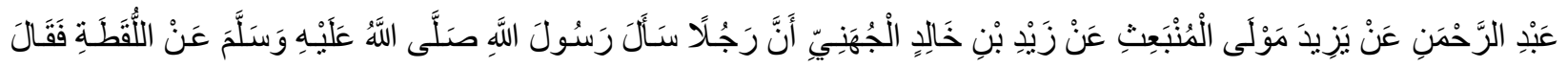

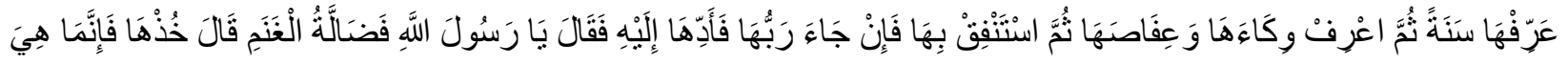

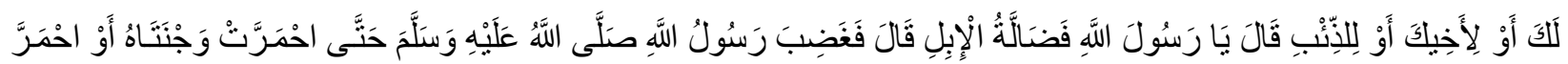

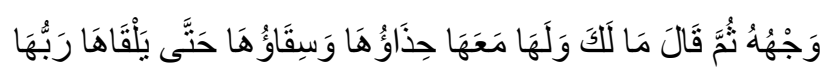

Dan telah menceritakan kepada kami Yahya bin Ayyub dan Qutaibah dan Ibin Hujr. Ibnu Hujr berkata; telah mengabarkan kepada kami, sedangkan yang dua orang mengatakan; telah menceritakan kepada kami Isma'il -yaitu Ibnu Ja'far- dari Rabi'ah bin Abu Abdurrahman dari

\footnotetext{
${ }^{8}$ Abu al-Husain Muslim Ibn al-Hajaj al-Imam al-Hafizh , Shahih Muslim, ( Bandung, Dahlan, tt), h. 408-
} 409 
Yazid -bekas budak Al Munba'its- dari Zaid bin Khalid Al Juhani bahwa seorang laki-laki bertanya kepada Rasulullah shallallahu 'alaihi wasallam tentang barang temuan, lalu beliau bersabda: "Umumkanlah selama setahun, lalu kenalilah wadah dan talinya setelah itu manfaatkanlah ia, jika pemiliknya datang maka berikanlah barang tersebut kepadanya." Kemudian orang itu bertanya lagi, "Wahai Rasulullah, bagaimana dengan kambing yang hilang?" Beliau menjawab: "Ambillah, mungkin ia dapat menjadi milikmu atau milik saudaramu atau bahkan menjadi milik serigala." Dia bertanya lagi, "Wahai Rasulullah, bagaimana jika yang ditemukan adalah unta?" Zaid bin Khalid berkata, "Maka Rasulullah shallallahu 'alaihi wasallam marah hingga wajahnya memerah, kemudian beliau bersabda: "Apa urusanmu dengan unta yang hilang? Ia telah membawa sepatu (punya kaki) dan wadah airnya sendiri hingga ia bertemu pemiliknya."

No. 3249

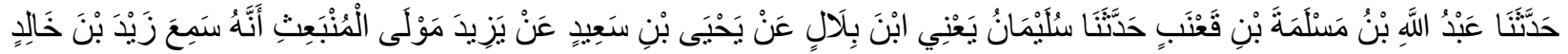

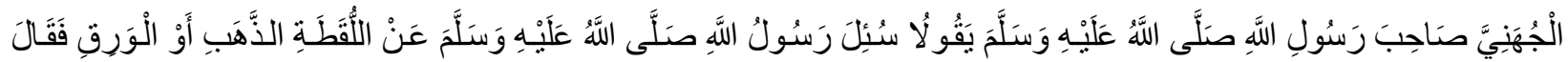

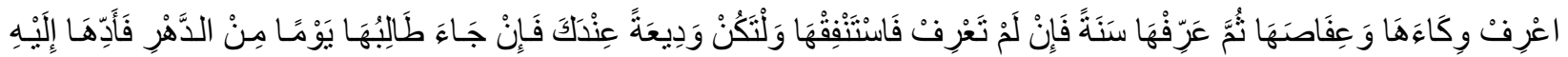

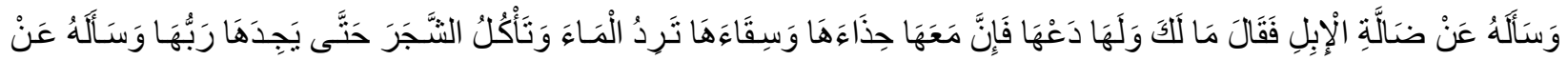

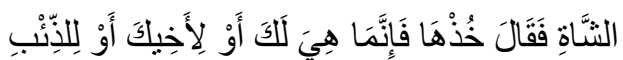

Telah menceritakan kepada kami Abdullah bin Maslamah bin Qa'nab telah menceritakan kepada kami Sulaiman -yaitu Ibnu Bilal- dari Yahya bin Sa'id dari Yazid -bekas budak Al Munba'its- bahwa dia mendengar Zaid bin Khalid Al Juhani salah seorang sahabat Rasulullah shallallahu 'alaihi wasallam berkata, "Rasulullah shallallahu 'alaihi wasallam pernah ditanya mengenai barang temuan yang berisi emas atau perak." Maka beliau bersabda: "Kenalilah wadah dan talinya, kemudian umumkanlah selama setahun, apabila pemiliknya tidak datang untuk mengenalinya, maka -untuk sementara waktu- kamu boleh memanfaatkan, dan itu sebagai barang titipan untukmu. Seandainya di suatu hari pemiliknya datang mencari barang tersebut, maka berikanlah barang tersebut kepadanya." Lalu dia bertanya menegani temuan unta, maka beliau balik bertanya kepada dia: "Apa urusanmu dengan unta yang hilang? Biarkanlah unta itu pergi, karena ia membawa sepatu (punya kaki) dan wadah airnya sendiri. Ia dapat mendatangi mata air dan makan dedaunan sampai ia bertemu pemiliknya." Orang itu bertanya lagi mengenai temuan kambing, beliau menjawab: "Ambillah ia, mungkin ia dapat menjadi milikmu atau milik saudaramu atau bahkan menjadi milik serigala." 
No. 3250

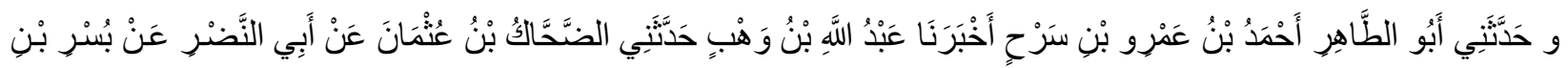

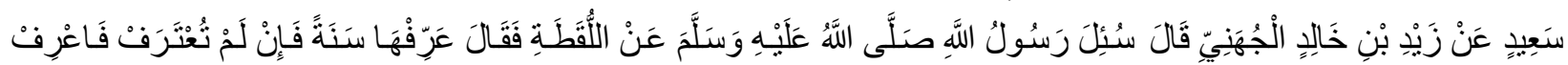

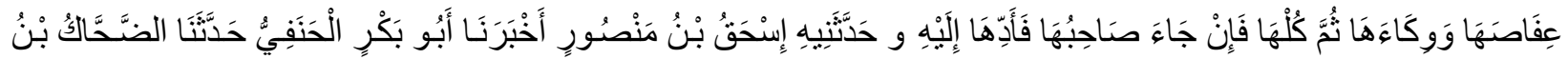

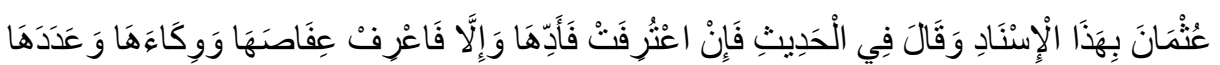

Telah menceritakan kepadaku Abu At Thahir Ahmad bin 'Amru bin Sarh telah mengabarkan kepada kami Abdullah bin Wahb telah menceritakan kepadaku Adl Dlahak bin Utsman dari Abu An Nadlr dari Busr bin Sa'id dari Zaid bin Khalid Al Juhani dia berkata, "Rasulullah shallallahu 'alaihi wasallam pernah ditanya mengenai barang temuan, maka beliau menjawab: "Umumkanlah sampai setahun lamanya, jika ada orang yang mengenalinya, maka kenalilah tali dan wadahnya kemudian makanlah, jika pemiliknya datang maka kembalikanlah ia kepadanya." Dan telah menceritakan kepadaku Ishaq bin Manshur telah mengabarkan kepada kami Abu Bakar Al Hanafi telah menceritakan kepada kami Ad Dlahak bin Utsman dengan isnad ini, dan dia menyebutkan dalam haditsnya, "Jika pemiliknya mengenailnya, maka kembalikanlah ia kepadanya, jika tidak (dapat mengenalinya) maka kenalilah tali, wadah dan jumlahnya." c. al-Tirmidzi dalam Sunan-nya Kitab al-Ahkam No. $1293^{9}$

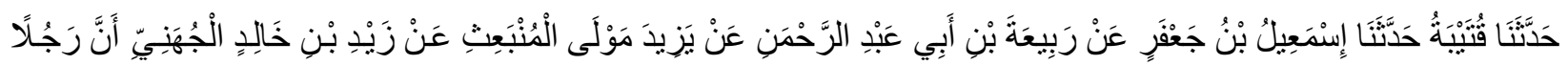

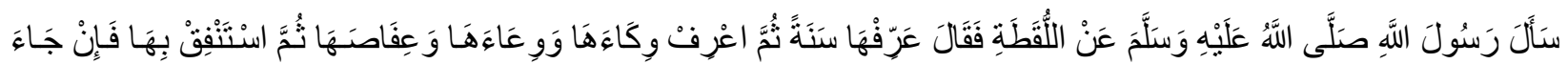

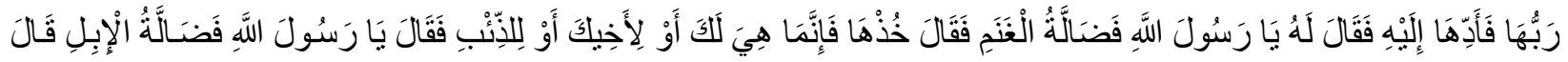

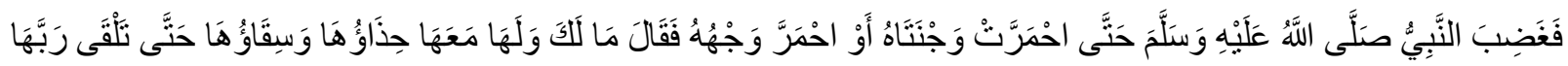

Telah menceritakan kepada kami Qutaibah, telah menceritakan kepada kami Isma'il bin Ja'far dari Rabi'ah bin Abu Abdurrahman dari Yazid mantan budak Al Munba'its dari Zaid bin Khalid Al Juhani bahwa ada seseorang bertanya kepada Rasulullah shallallahu 'alaihi wasallam tentang barang temuan, beliau pun menjawab: "Umumkanlah selama satu tahun kemudian umumkanlah tali pengikat, bejana dan isinya. Setelah itu belanjakanlah ia, namun jika datang pemiliknya maka serahkanlah kepadanya." Lalu ia bertanya kepada beliau; Wahai Rasulullah, ia berupa kambing yang hilang. Maka beliau menjawab: "Sesungguhnya itu menjadi milikmu, saudaramu atau milik serigala." Ia bertanya lagi; Wahai Rasulullah, bagaimana dengan unta yang hilang? Ia menceritakan; Lalu Nabi shallallahu 'alaihi wasallam pun marah hingga memerah

${ }^{9} \mathrm{Abu}$ 'Isa al-Turmidzi, Sunan al-Tirmidziy, ( Semarang, Karya Toha Putera, tt), h. 45 
kedua pipi atasnya atau memerah wajahnya seraya mengatakan: "Itu bukan milikmu dan baginya apa yang ia bawa berupa sepatu dan tempat minumnya hingga ia bertemu dengan pemiliknya."

d. Abu dawud dalam Sunan-nya Kitab al-Luqthah, N0. 1451, 1452, $1453^{10}$

No. 1451

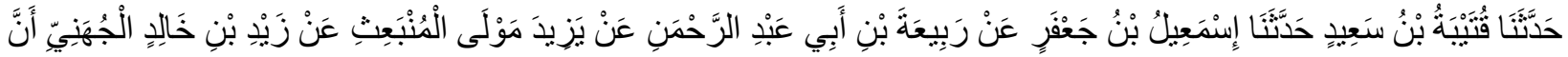

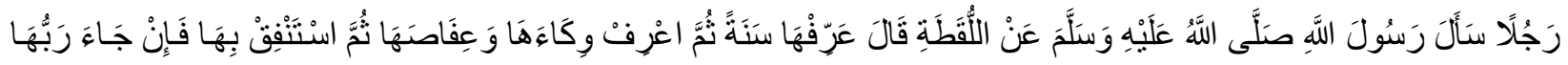

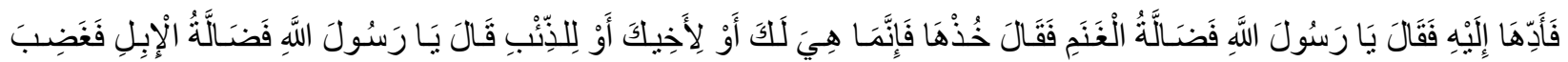

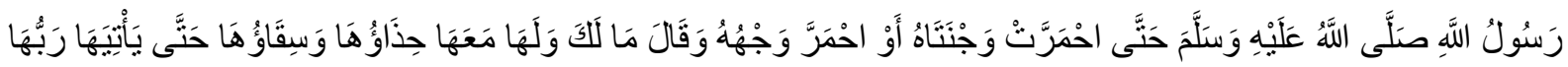

Telah menceritakan kepada Kami Qutaibah bin Said, telah menceritakan kepada Kami Isma'il bin Ja'far, dari Rabi'ah bin Abu Abdurrahman, dari Yazid mantan budak Al Munba'its, dari Zaid bin Khalid Al Juhani, bahwa seorang laki-laki bertanya kepada Rasulullah shallAllahu wa'alaihi wa sallam mengenai barang temuan, beliau berkata: "Umumkan satu tahun, kemudian ketahuilah talinya dan kantongnya kemudian nafkahkan kepada dirimu. Apabila pemiliknya datang maka berikan kepadanya." Lalu orang tersebut berkata; wahai Rasulullah, bagaimana dengan kambing yang tersesat? Beliau bersabda: "Ambillah kambing tersebut, sesungguhnya kambing tersebut adalah milikmu atau saudaramu atau milik serigala." Ia berkata; wahai Rasulullah, bagaiamana dengan unta yang tersesat? Kemudian Rasulullah shallAllahu wa'alaihi wa sallam marah hingga kedua pipinya atau wajahnya memerah. Beliau berkata: "Apa urusanmu dengannya? Ia memiliki sepatu, dan kantong air minum hingga pemiliknya mendapatkannya." Telah menceritakan kepada Kami Ibnu As Sarh, telah menceritakan kepada Kami Ibnu Wahb, telah mengabarkan kepadaku Malik dengan sanad dan maknanya. Ibnu Wahb menambahkan; kantong air minum, unta tersebut minum air dan memakan pohon. Dan beliau tidak mengatakan: "Ambillah kambing yang hilang." Dan beliau berkata mengenai barang temuan: "Umumkan selama satu tahun, apabila pemiliknya telah datang maka berikan kepadanya, jika tidak maka urusanmu dengannya."

1452

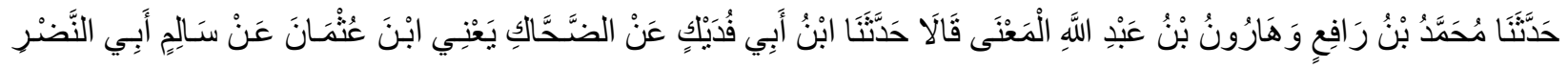

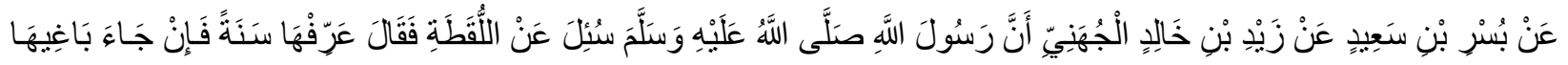

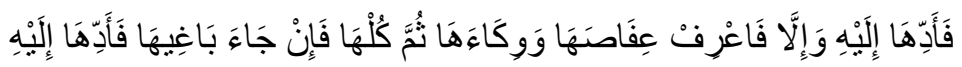

${ }^{10}$ Shidqiy Muhammad Jamil, Sunan Abi Daud, Lil-Hafizh Abi Daud Sulaiman bin al-Asy 'ats al-Sajtani, Juz.1, Bab.65, ( Beirut-Lebanon, Dar-al-KOTTOB al-ILMIYAH,1998), h. 50 
Telah menceritakan kepada Kami Muhammad bin Rafi', dan Harun bin Abdullah secara makna, mereka berkata; telah menceritakan kepada Kami Ibnu Abu Fudaik dari Adh Dhahhak yaitu Ibnu Utsman dari Salim Abu An Nadhr dari Busr bin Sa'id dari Zaid bin Khalid Al Juhani bahwa Rasulullah shallAllahu wa'alaihi wa sallam ditanya mengenai barang temuan. Kemudian beliau berkata: "Umumkan selama satu tahun, kemudian apabila orang yang mencarinya telah datang maka berikan kepadanya, jika tidak maka katahuilah kantongnya dan talinya kemudian makanlah, kemudian apabila orang yang mencarinya telah datang maka kembalikan kepadanya." 1453

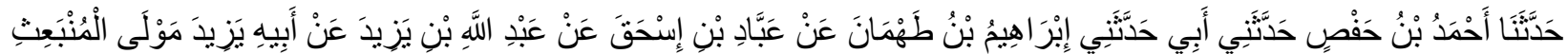

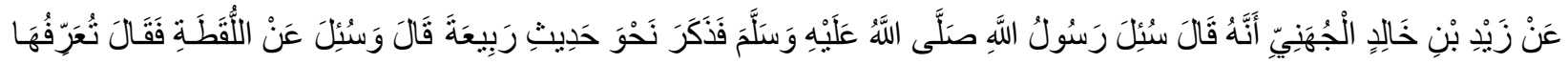

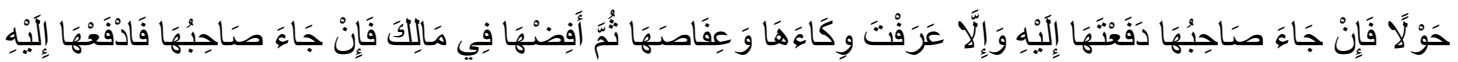

Telah menceritakan kepada Kami Ahmad bin Hafsh, telah menceritakan kepadaku ayahku, telah menceritakan kepadaku Ibrahim bin Thahman, dari 'Abbad bin Ishaq dari Abdullah bin Yazid dari ayahnya yaitu Yazid mantan budak Al Munbaits dari Zaid bin Khalid Al Juhani bahwa ia berkata; Rasulullah shallAllahu wa'alaihi wa sallam ditanya ..... kemudian ia menyebutkan seperti hadits Rabi'ah. Ia berkata; dan beliau ditanya mengenai barang temuan, lalu beliau mengatakan: "Engkau umumkan selama satu tahun, kemudian apabila pemiliknya telah datang maka engkau serahkan kepadanya, jika tidak engkau ketahui talinya dan kantongnya, kemudian masukkan ke dalam hartamu, kemudian apabila pemiliknya datang maka serahkan kepadanya."

e. Ibnu Majah dalam Sunan-nya Kitab al-Ahkam, No. $2495^{11}$

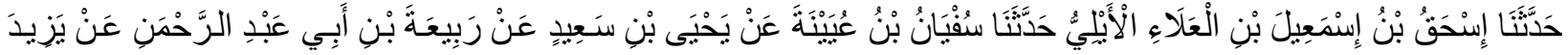

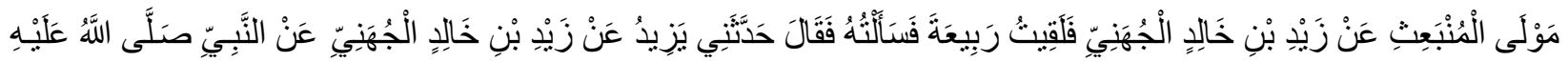

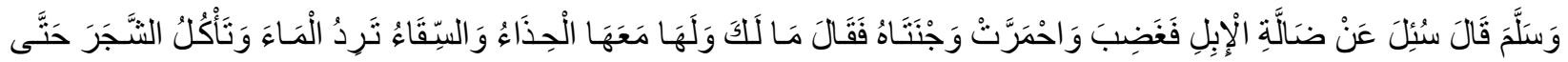

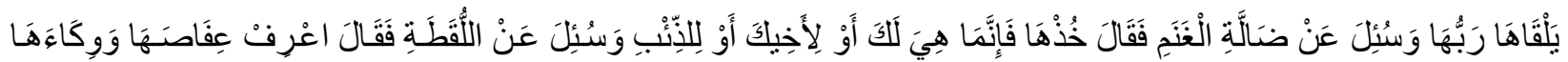

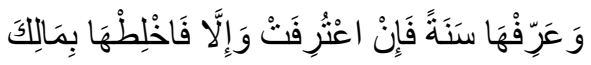

Telah menceritakan kepada kami Ishaq bin Isma'il bin Al 'Ala Al Aili berkata, telah menceritakan kepada kami Sufyan bin Uyainah dari Yahya bin Sa'id dari Rabi'ah bin Abu 'Abdurrahman dari Yazid -mantan budak Al Munba'its- dari Zaid bin Khalid Al Juhani aku bertemu Rabi'ah maka aku tanyakan kepadanya, ia berkata; Yazid menceritakan kepadaku dari

\footnotetext{
${ }^{11}$ Abi Abdillah Muhammad bin Yazid al-Qazwinniy, Sunan Ibnu Majah, Juz.1, Bab,60 (Beirut- Lebanon, Dar al-KOTOB al- ILMIYAH, 1998), h. 256
} 
Zaid bin Khalid Al Juhani- dari Nabi shallallahu 'alaihi wasallam, ia berkata, "Beliau pernah ditanya tentang seekor unta yang tersesat, maka beliau marah dan wajahnya memerah, beliau bersabda: "Apa urusanmu dengan unta tersebut, ia masih punya kaki, bisa minum air dan makan pepohonan hingga pemiliknya menemukannya! " Lalu beliau ditanya tentang kambing yang tersesat, maka beliau bersabda: "Ambillah kambing tersebut, sebab ia milikmu, atau milik saudaramu, atau bahkan milik serigala." Dan beliau juga ditanya tentang barang temuan, beliau bersabda: "Kenalilah bejana dan tali pengikatnya, setelah itu umumkanlah selama satu tahun, jika temuan itu dikenali maka berikanlah, namun jika tidak maka campurlah dengan harta milikmu."

f. Ahmad bin Hanbal dalam Musnad-nya Kitab Musnad al-Tsamiyyin, No. 16431, $20697^{12}$

No. 16431

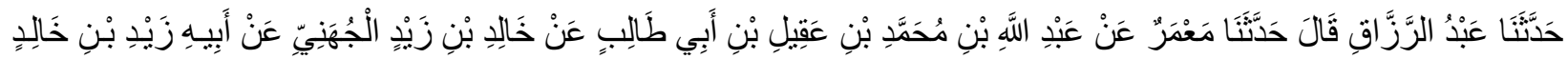

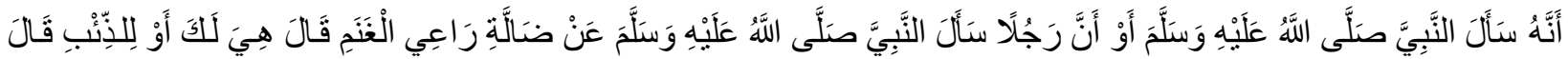

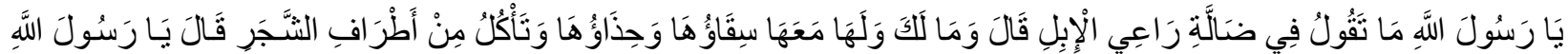

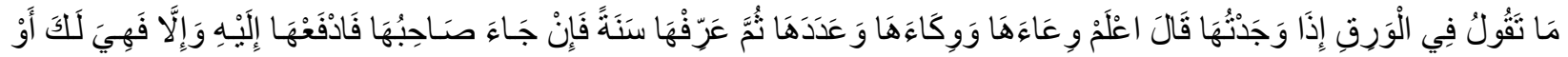
اسنتَنْتِعْ بِهَا أَوْْ نَحْوَ هَذَّا

Telah menceritakan kepada kami Abdurrazzaq berkata; Telah menceritakan kepada kami Ma'mar dari Abdullah bin Muhammad bin 'Aqil bin Abu Thalib dari Khalid bin Zaid Al Juhani dari Bapaknya, Zaid bin Khalid sesungguhnya dia bertanya kepada Nabi Shallallahu'alaihiwasallam -atau kisahnya ada seorang laki-laki yang bertanya kepada Nabi Shallallahu'alaihiwasallam-- tentang unta yang hilang. Beliau bersabda: "Itu menajadi milikmu atau untuk srigala." (Zaid bin Khalid Al Juhani Radliyallahu'anhu) berkata; Wahai Rasulullah, bagaimana pendapat anda tentang unta yang hilang". Beliau bersabda: "Janganlah kau ambil, karena unta itu bisa membawa tempat minumnya dan kakinya dan bisa memakan pohon-pohon yang ada." (Zaid bin Khalid Al Juhani Radliyallahu'anhu) berkata; "Wahai Rasulullah, bagaimana pendapat anda tentang uang yang saya temukan?." Beliau bersabda: "Umumkanlah

12 al-Iman Ahmad bin Hanbal, Syarah Hamzah Ahmad Zain, Juz 9 ( al-Qahirah, Darul Hadits, tt), h.561, No. hadits. $10716, \&$ h. 90 , No. hds. 7171 
kantongnya, tutupnya dan jumlahnya, lalu umumkanlah selama setahun. Jika datang pemiliknya maka serahkanlah barang itu, jika tidak, maka itu menjadi milikmu atau manfaatkanlah."atau dengan redaksi yang semisalnya.

No. 16422

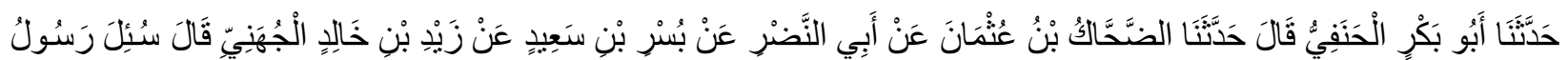

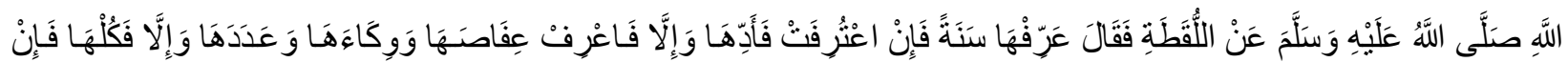

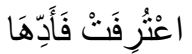

Telah menceritakan kepada kami Abu Bakar Al Hanafi berkata; Telah menceritakan kepada kami Al Dlahak bin 'Utsman dari Abu Nadlr dari Busr bin Sa'id dari Zaid bin Khalid Al Juhani berkata; Nabi Shallallahu'alaihiwasallam ditanya tentang barang temuan. Beliau bersabda: "Umumkanlah selama satu tahun! Jika ada yang mengakuinya maka serahkanlah jika tidak ada maka umumkanlah kantongnya, tutupnya dan jumlahnya. Jika tetap tidak ada maka makanlah, jika ada yang mengakuinya maka serahkanlah."

No. 20697

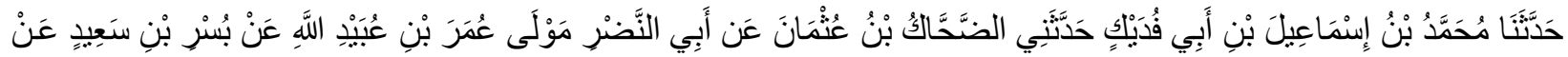

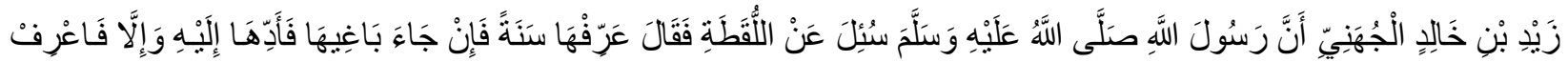

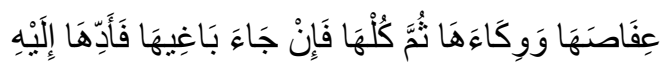

Telah menceritakan kepadaku Muhammad bin Isma'il bin Abu Fudaik telah menceritakan kepadaku Adl Dlahak bin Utsman dari Abu Nadlr budak Umar bin Ubaidullah, dari Busr bin Said dari Zaid bin Khalid Al Juhanni, bahwa Rasulullah shallallahu 'alaihi wasallam ditanya tentang luqathah (barang temuan), beliau bersabda: "Umumkan dia hingga setahun, bila datang pemiliknya maka berikanlah, jika tidak maka sebutkanlah sifat dan bentuknya, jika (makanan yang mudah busuk) maka makanlah dan jika datang pemiliknya maka gantilah!"

g. Malik dalam al-Muatha' Kitab al-Iqdhiyah, No. $1248^{13}$

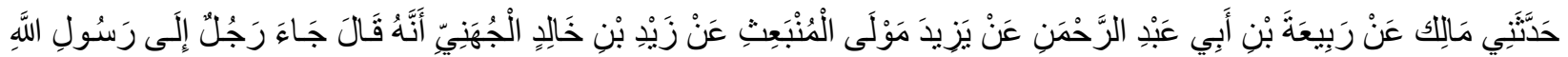

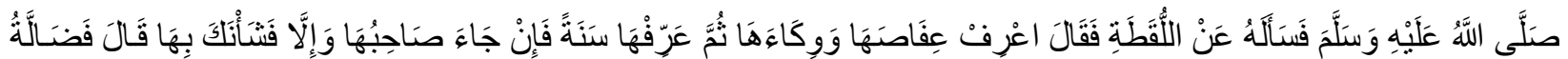

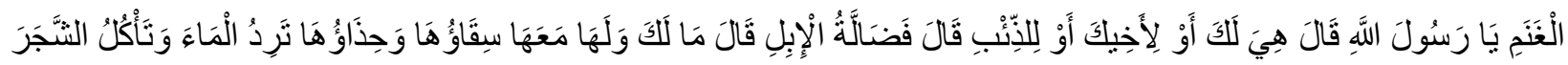
حَتَّى يَلْقَهَهَا رَبْهُها

Telah menceritakan kepadaku Malik dari Rabi'ah bin Abu Abdurrahman dari Yazid budak Al Munba'its, dari Zaid bin Khalid AL Juhani ia berkata; "Seorang laki-laki menemui

${ }^{13}$ Shiddiqiy Jamil al-'Atthar, al-Mu'attha' (Beirut Dar-al-KOTTOB, 2002), h.450-451 
Rasulullah shallallahu 'alaihi wasallam bertanya tentang Luqathah (barang temuan), beliau lalu bersabda: 'Kenalilah tutup dan talinya, lalu umumkan selama satu tahun. Jika pemiliknya datang maka berikanlah, dan jika tidak maka itu menjadi milikmu." laki-laki itu bertanya lagi, "Wahai Rasulullah, bagaimana dengan kambing yang tersesat?" Beliau menjawab: "Kambing itu untukmu, atau untuk saudaramu, atau untuk serigala." Laki-laki itu bertanya lagi; "Bagaimana dengan unta yang tersesat? ' beliau menjawab: "Apa urusanmu dengan unta, ia bisa minum dan punya kaki! Ia akan mencari minum dan makannya sendiri hingga bertemu dengan pemiliknya."

Dari teks hadis tersebut tampak mempunyai jalur sanad yang berbeda, baik nama perawi yang menyampaikan riwayat itu kepada para mukharrij, demikian pula shigat tahammul ( lambang) yang digunakan, untuk mengetahui lebih jelas tentang perawi hadis yang terlibat di dalam rangkaian sanad hadis yang telah ditakhrij dengan melakukan I'tibar sanad yakni menyertakan sanad jalur yang lain sehingga dapat ditemukan metode periwayat hadis yang berstatus muttabi' dan syahid atas hadis tersebut.

\section{I'tibar Sanad.}

Mengenai I'tibar sanad ini tujuannya untuk mengetahui keadaan jalur sanad hadis yang ada dalam seluruh sanad hadis dalam satu skema sehingga akan tampak masing-masing lambang periwayatan yang digunakan oleh perawi dilihat dari segi muttabi' ( pendukung) ada atau tidak ada yang mendukung dari perawi yang dikritik oleh ulama tentang ke-tsiqahannya sehingga riwayat yang disampaikan itu bersambung atau mutashil sampai kepada Nabi Muhammad sehingga dapat mengangkat status derajat hadis itu.

Untuk lebih jelanya agar sanad hadis tersebut dapat dengan mudah difahami dalam kegiatan I'tibar maka perlu adanya pembuatan skema dari seluruh hadis yang dikaji. Dalam skema tersebut akan tampak jalur antara periwayat yang satu dengan yang lainnya. Dibawah ini digambar skema sanad hadis yang dikaji yaitu: 
Dari Skema tersebut diketahui bahwa tahammu al-Ada al-Hadis yang digunakan bervariasi, yakni akhbarana, haddatsana, haddatsani, 'an dan sami'tu ini menunjukkan bahwa dari masing-masing perawi mempunyai metode yang berbeda-beda.

\section{Penelitian Sanad dan Matan Hadis}

Karena sanad hadis yang akan diteliti sebagaimana yang diketahui melalui kegiatan takhrij dan i'tibar sanad berjumlah banyak, maka salah satu sanad yang ada, dapat dipilih untuk diteliti langsung secara cermat. Kaitannya dengan ini, sanad yang dipilih untuk diteliti adalah yang terdapat pada jalur al-Mu'atha' dengan sanad Malik, yaitu yang Hadis datang dari Zaid bin Khalid melalui Yazid Mawla Munba'its dan Malik sendiri sebagai perawi terakhir. Uraian tersebut secara berurutan akan dimulai dari Malik sebagai sanad terakhir, sampai pada Yazid bin Khalid sebagai perawi pertama sebagai berikut: 1) Zaid bin Khalid sebagai periwayat pertama Sanad terakhir 2) Yazid Mawla Munba'its sebagai periwayat II Sanad 3, 3) Rabi' bin Abi Abd. al-Rahman periwayat III Sanad 2 dan 4) Malik sebagai periwayat terakhir dan sekaligus sebagai al-Mukharrij al-Hadits ${ }^{14}$

\section{Zaid bin Khalid al-Juhani}

Nama lengkapnya adalah Zaid bin Khalid adalah seorang Shahabat Rasulullah Saw di nisbatkan dengan al-Juhany al-Madiny mempunyai nama kun-yah : Abu Abd. al-Rahman. Lahir di Kufah dan wafat di Madinah pada tahun 68 H. Guru-gurunya Zaid bin Khalid berguru dan menerima Hadis selain langsung dari Rasulullah juga dari kalangan sahabat dan banyak ulama, di antaranya adalah, Aisyah binti Abi Bakar al-Shiddiq, Utsman bin Affan bin Abi al-'Ash bin Umayyah, Ali bin Abi Thalib, al-Zubair bin al-'Awwam, Zaid bin Sahl bin al-Aswad, Thalhah bin Ubaidillah bin Utsman, dan Ubay bin Ka’af bin Qais

Muridnya antara lain Abu 'Amrah Mawla Zaid bin Thalhah, Basir bin Sa'id Mawla alHadhramy, Khalid bin Zaid, Khalad bin al-Saib bin Khalad, Abu Shalih, Zaid bin Aslam, al-Saib bin Khalad bin Suwaid, Sa'id bin al-Musayyab bin Hazn, Sufyan bin Hani', Shalih bin Nabhin, Abd. al-Rahman bin Abi Amrah, Abdullah bin Abd. al-Rahman, Abdillah bin Qais bin Makhramah, Ubaidillah bin Abdillah bin Utbah bin Mas'ud, Urwah bin al-Zubair bin alAwwam, Atha' bin Abi Rabah Aslam, Atha' bin Yasar dan Yazid Mawla Munbaits. Pernyataan Ulama Hadits tentang dirinya adalah Shahabat para ulama hadis telah bersepakat bahwa sahabat tidak diragukan lagi kredibilatas kedhabit-an dan ke-tsiqahan-nya.

\footnotetext{
${ }^{14}$ Ibnu Hajar al-Asqalani, Tahdzib al-Tahdzib, (India, Majelis Dairah al-Ma'arif al-Nizamiyah, 1982), h.
} 605 


\section{Yazid Mawla Munba'its}

Nama lengkapnya adalah Yazid Mawla al-Munbaits, termasuk salah satu ulama pertengahan dari al-Tabi'in, lahir di Madinah. Guru-gurunya. Yazid berguru dan menerima hadits dari kalangan sahabat di antaranya adalah Abu Hurairah dan Zaid bin Khalid al-Juhaniy.. Murid-muridnya antara lain Abdullah bin Yazid, Abd. al-Malik bin Isa bin Abd. al-Rahman, Yahya bin Sa’id bin Qais dan Rabi'ah bin Abi Abd. al-Rahman

Pernyataan Ulama Hadits tentang dirinya adalah:

1. Ibnu Hibban menuturkan bahwa Yazid Mawla Munbai'its dalam keadaan tsiqah.

2. Al-Dzaby berkata, Yazid Mawla Munba'its termasuk seorang yang $t \operatorname{siq} h^{15}$.

Berdasarkan pernyataan ulama hadits di atas bahwa Yazid Mawla munba'its adalah seorang yang shaduq. Maka pernyataannya bahwa Yazid telah menerima hadits dari Sahabat Zaid bin Khalid dapat dipercaya. olehnya itu dapat disimpulkan bahwa sanad antara Zaid bin Khalid dengan Yazid Mawla Munbaits adalah bersambung.

\section{Rabi’ah bin Abi Abd. al-Rahman}

Nama lengkapnya adalah Rabi'ah bin Abi Abd. al-Rahman Farwa, termasuk ulama alShaghir min al-Tabi'in, nama kun-yah: Abu Utsman, nama al-Laqab (julukan) Rabi'ah al-Ra'yi lahir di Madinah wafat di al-Anbar pada tahun $136 \mathrm{H}$.

Guru-gurunya Rabi'ah bin Abi Abd. al-Rahman berguru dan menerima hadits banyak dari kalangan ulama antara lain, Ibnu bin Utsman bin Affan, Anas bin Malik bin al-Nadhr bin Dhamdham bin Zaid bin Haram, al-Harits bin Bilal bin al-Harits, Hanzhalah bin Qais bin Amr, Kharjah bin Zaid bin Tsabit, Rabi'ah bin Abdillah bin al-Hadir, Salim bin Abdillah bin Umar bin al-Khaththab, Sa'id bin al-Musayyab, Sulaiman bin Yasir, Sahil bin Abi Shalih Dzakwan, Abd. al-Rahman bin Hurmuz, dan Rabi'ah bin Abd. al-Rahman.

Murid-muridnya antara lain Ismail bin Ja'far bin Abi Katsir, Anas bin Iyadh, Hamad bin Maslamah bin Dinar, Dawud bin Khalid bin Dinar, Sa'id bin Abi Hilal, Sufyan bin Sa'id bin Masruq, Sufyan bin Abi Uyainah dan Malik

Pernyataan Ulama Hadits tentang dirinya adalah:

1. Ahmad bin Hanbal, al-'Ajaly, Muhammad bin Sa'd, Abu Hatim al-Razy dan al-Nasa'iy, menyatakan bahwa Rabi'ah bin Abi Abd. al-Rahman adalah seorang yang tsiqah.

2. Ya'kub bin Syaibah berkata, bahwa Rabi'ah bin Abi Abd. al-Rahman adalah tsiqah.

${ }^{15}$ Shihab al-Din Ahmad ibn Ali ibn Hajar al-Asqalani, Kitab Tahdzib al-Tahdzib, JEd. Shidqi Jam'il al-Ar (Beirut Dar al-Fikr, 1415/1995),h. 102 
Berdasarkan pernyataan ulama hadits di atas bahwa Rabi'ah bin Abi Abd. al-Rahman adalah seorang yang tsiqah. Maka pernyataannya bahwa Rabi'ah bin Abi Abd. al-Rahman telah menerima hadits dari Yazid dapat dipercaya. olehnya itu dapat disimpulkan bahwa sanad antara Yazid Mawla Munbaits dengan Rabi’ah bin Abi Abd. al-Rahman adalah bersambung.

\section{Malik ibn Anas.}

Nama lengkapnya adalah Malik ibn Anas ibn Malik ibn Abi Amir ibn Amr ibn al-Harits ibn Utsman ibn Jutsail ibn Amr ibn al-Harits. Beliau adalah salah seorang ulama terkenal dan Imam kota Madinah. ${ }^{16}$ Masa hidupnya, Malik lahir pada tahun $93 \mathrm{H}$ ( ada yang menyebutkan tahun $90 \mathrm{H}$ ), dan wafat pada tahun $169 \mathrm{H}$ dalam usia 87 tahun, setelah menjadi mufti di Madinah selama 60 tahun. Ibn Hajar menyebutkan bahwa Malik meninggal dunia pada tahun $179 \mathrm{H}$.

Guru-gurunya. Malik berguru dan menerima Hadis dari banyak ulama, yang diperkirakan mencapai jumlah 900 orang. ${ }^{17}$ Di antara mereka adalah Amir ibn Abdillah ibn al-Zubair ibn alAwwam, Na'im ibn Abdallah al-Majmar, Zaid bin Aslam, Nafi' Mawla ibn Umar, Abdallah bin Dinar, Nafi' adalah sanad pertama bagi Hadis Malik di atas. Murid-muridnya adalah al-Zuhri, Yahya ibn Sa'id al-Anshari, al-Awza'i, al-Tsawri Syu'bah ibn al-Hajjaj, ibn al-Juraij, al-Laits ibn Sa'd dan Ibn Uyainah.

Adapun pernyataan kritikus Hadis tentang dirinya. Mengenai pribadi Malik, para kritikus

Hadis berpendapat:

1. Muhammad ibn Ishaq al-Tsaqafi berkata, "ketiak Muhammad bin Ismail al-Bukhari ditanya tentang Asshah al-Asanid, al-bukhari mengatakan, " Ashah al-Sanid adalah Malik dari Nafi" dari Ibnu Umar"

2. Ali ibn al-Madini berkata, dari sumber Ibnu 'Uyainah" Malik adalah orang yang paling teliti, dan kritis terhadap para perawi Hadis serta sangat mengetahui keadaan mereka."

3. Berkata Ali, " Saya tidak mengetahui bahwa Malik meninggalkan ( tidak meriwyatkan Hadis ) dari beberap perawi, kecuali mereka yang memiliki sesuatu (cacat) pada riwayat mereka. "Berkata al-Dawri, dari Ibn Ma'in, "Setiap perawi yang menjadi sumber Malik dalam pengambilan Hadis adalah tsiqah, kecuali 'Abd. al-Karim.

4. Abdullah ibn Ahmad mengatakan, "Aku bertanya kepada ayahku, "Siapakah yang paling terpercaya di antara sahabat al-Zuhri? " Ayahku menjawab, " Malik, Malik adalah yang paling terpercaya dalam segala hal.

5. Ibn Sa'd berkat, " Saya adalah orang yang paling ingat tentang waktu wafatnya Malik adalah bulan Shafar tahun $179 \mathrm{H}$, dan Malik adalah orang yang tsiqah, terpercaya, wara', faqih, alim, dan Hujjah. ${ }^{18}$

Dari komentar ulama Hadis di atas terlihat secara jelas bahwa Malik adalah orang yang tsiqah, paling terpercaya, teliti dan kritis terhadap perawi hadis, dan bahkan termasuk bagian

\footnotetext{
${ }^{16}$ Shihab al-Din Ahmad ibn Ali ibn Hajar al-Asqalani, Kitab Tahdzib al-Tahdzib, JEd. Shidqi Jam'il al-Ar (Beirut Dar al-Fikr, 1415/1995),h.6

${ }^{17}$ Sa'id al-Lahham dalam al-Muwaththa', h.5

${ }^{18}$ Op. cit. Juz 8. h. 6
} 
dari ashah al-sanid ( yaitu Malik dari Nafi' dari Ibnu Umar. Oleh karenanya, pernyataan bahwa dirinya telah menerima riwayat hadis dari Nafi' dan Ibnu Umar dapat dipercaya. Dan karenanya pula dapat dikatakan bahwa sanad antara Malik dan Nafi'dan Abdullah ibn Umar adalah dalam keadaan bersambung (Mutashil).

Dari segi lambang-lambang periwayatan Hadis di atas tergolong ти an an dan mu'anan, yang diperselisihkan tentang ketersambungan sanad-nya oleh para ulama hadis. Namun setelah dilakukan penelitian tentang kualitas pribadi para periwayatnya dan hubungan periwayat tersebut seluruh sanad-nya dinyatakan dalam keadaan bersambung (mutashil). Berdasarkan uraian di atas, maka dapat ditarik kesimpulan bahwa sanad Hadis yang di-takhrij oleh Malik, hukumnya adalah Shahih dan dapat dijadika Hujjah

Perawi hadis yang disebutkan ini memiliki ketersamabungan sanad, dan masing-masing mereka memiliki sifat yang terpuji, tsiqah, tsabbata, 'Adl dan sifat terpuji lainnya. ${ }^{19}$ Sehingga dapat dinyatakan bahwa hadisnya kuat dan dapat diterima. Karena sanad hadis tersebut bersambung, dan dari segi periwayatnya adalah makbul, jadi dapat dinyatakan bahwa hadis yang dimaksud adalah berstatus hadis marfu' karena semua sanad terakhirnya disandarkan kepada Nabi saw dengan menyatakan : قان (عن) رسو ل الله صلى الله عليه وسلم atau

Selanjutnya dalam kegiatan penelitian matan ulama menempuh cara yang berbeda-beda pula. Berkaitan dengan ini, maka penelitian matan yang penulis lakukan adalah merujuk pada rumusan yang ditetapkan oleh Salahuddin al-Adlabi dan al-Khatib al-Bagdadi bahwa matan suatu hadis shahih apabila sanadnya shahih, tidak bertentangan dengan al-Qur'an dan hadis shahih pada matan tersebut tidak terdapat ziyadah yang rancu bahasanya. ${ }^{20}$

Dengan adanya rumusan kriteria keshahian matan yang telah disebutkan, dan jika digunakan kaidah صحيح السنــ المستن , maka matan hadis yang diteliti dapat diterima, karena dari uraian penelitian sanad sebelumnya telah ditetapkan bahwa sanad yang diteliti dari jalur Malik adalah berkualitas shahih. Di samping itu hadis yang diteliti ini bagaimana menyikapi tentang seputar hukum barang temuan.

Berdasarkan pada tolok ukur matan ( Ma'ayir al-matn), di atas, maka dapat disimpulkan bahwa matan hadis yang diteliti berkualitas shahih, dilihat dari persambungan sanadnya mutashil, dilihat dari pihak yang disandarinya pada akhir matan marfu', dilihat dari penyandaran beritanya nabawi

\section{Mufradat al-Hadits}

${ }^{19}$ Ibid, Juz. 8, h. 10

${ }^{20}$ Salahuddin bin Ahmad al-Adlab, Manhaj al-Naqd al-Mtn, (Beirut, Dar al-Ma'arif al-Nizamiyyah, 1983), h. 236 


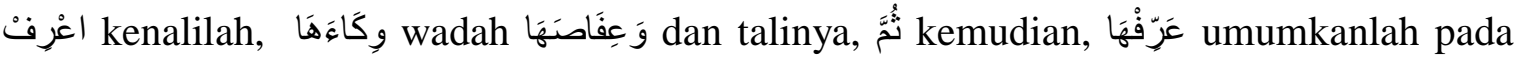

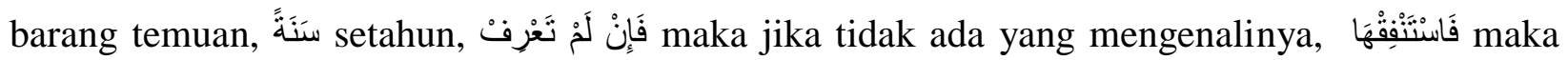

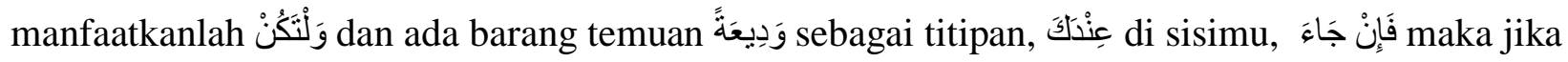

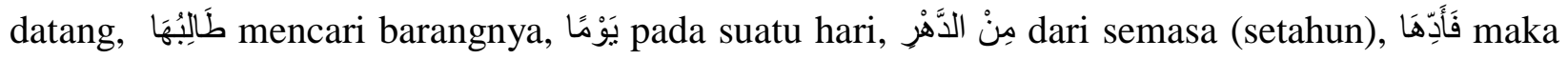
berikanlah, إِلَيْهِ pada pemiliknya.

Asbabul Wurud Hadits

Pada suatu ketika Nabi shallallahu 'alaihi wa sallam pernah ditanya tentang barang temuan berupa emas atau perak. Maka beliau bersabda, "Ingatlah tali pengikat dan wadahnya, kemudian umumkan selama setahun. Jika barang tersebut tidak ada yang mengakuinya, maka gunakanlah. Hendaknya barang temuan itu dianggap sebagai barang yang dititipkan padamu. Jika pada suatu hari orang yang memintanya datang, maka hendaknya engkau berikan kepadanya." Beliau shallallahu 'alaihi wa sallam kemudian ditanya tentang (barang temuan berupa) kambing. Beliau bersabda, "Ambillah kambing tersebut karena itu bisa menjadi milikmu, atau milik saudaramu, atau (boleh jadi) milik serigala." Beliau shallallahu 'alaihi wa sallam lalu ditanya tentang (barang temuan berupa) unta. Beliau menjawab, "Apa urusanmu dengan unta itu? Dia memiliki simpanan air dan memiliki sepatu. Dia juga bisa mendatangi air dan memakan tanaman sampai ditemukan oleh pemiliknya."

\section{Syarah Hadis (Pemahaman Kandungan Hadis)}

\section{Hukum Seputar Barang Temuan}

al Luqathah (اللُقَطَةُ ) - dengan mendhammahkan huruf lam dan memfathahkan huruf qaf adalah harta (selain hewan) yang hilang dari pemiliknya. Agama yang lurus ini datang dengan penjagaan dan pemeliharaan terhadap harta. Agama ini juga datang dengan pemuliaan dan perhatian terhadap harta seorang muslim, di antaranya adalah dengan adanya aturan seputar barang temuan.

Tidak boleh bagi seseorang untuk mengambil barang temuan dengan berbagai jenisnya, kecuali jika dia merasa bisa amanah terhadap barang itu dan mampu untuk mengumumkan barang temuan yang memang butuh untuk diumumkan. Hal ini berdasarkan hadits dari Zaid bin Khalid Al Juhani radhiallahu 'anhu, beliau bersabda:

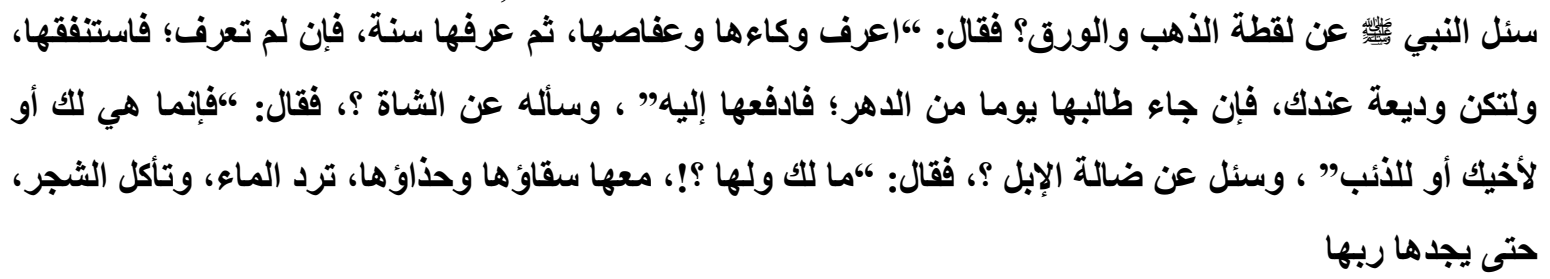


Terjemah

Pada suatu ketika Nabi shallallahu 'alaihi wa sallam pernah ditanya tentang barang temuan berupa emas atau perak. Maka beliau bersabda, "Ingatlah tali pengikat dan wadahnya, kemudian umumkan selama setahun. Jika barang tersebut tidak ada yang mengakuinya, maka gunakanlah. Hendaknya barang temuan itu dianggap sebagai barang yang dititipkan padamu. Jika pada suatu hari orang yang memintanya datang, maka hendaknya engkau berikan kepadanya." Beliau shallallahu 'alaihi wa sallam kemudian ditanya tentang (barang temuan berupa) kambing. Beliau bersabda, "Ambillah kambing tersebut karena itu bisa menjadi milikmu, atau milik saudaramu, atau (boleh jadi) milik serigala." Beliau shallallahu 'alaihi wa sallam lalu ditanya tentang (barang temuan berupa) unta. Beliau menjawab, "Apa urusanmu dengan unta itu? Dia memiliki simpanan air dan memiliki sepatu. Dia juga bisa mendatangi air dan memakan tanaman sampai ditemukan oleh pemiliknya."

Makna sabda beliau shallallahu 'alaihi wa sallam :

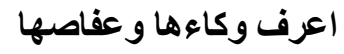

“Ingatlah 'wika' (الوكاء)dan 'ifash' ((العفاص) nya."

al-Wika (الوكاء) adalah sesuatu yang dipakai untuk mengikat kantung yang di dalamnya terdapat harta. Sedangkan makna al 'ifash ((العفاص) adalah kantung yang di dalamnya terdapat $\operatorname{harta}^{21}$.

Dan makna perkataan beliau shallallahu 'alaihi wa sallam :

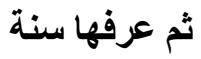

“...kemudian umumkan selama setahun."

Maksudnya, umumkan kepada orang-orang di tempat mereka berkumpul, seperti pasar, pintu-pintu masjid, tempat- tempat pertemuan dan pesta. Makna lafadz سنة (selama setahun) maksudnya : selama setahun penuh. Pada pekan pertama sejak ditemukannya, diumumkan setiap hari. Karena, pemiliknya lebih mungkin datang pada pekan tersebut. Setelah itu, diumumkan sesuai kebiasaan orang-orang dalam mengumumkan barang temuan. Hadits di atas menunjukkan wajibnya mengumumkan barang temuan.

Pada perkataan beliau shallallahu 'alaihi wa sallam :

"Ingatlah tali pengikat dan wadahnya ${ }^{22,}, \ldots$

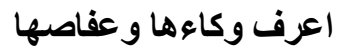

${ }^{21}$ Shalih al-Fauzan, al-Mulakhas al-Fikhi, (Madinah al-Munawarah: Salafiyah, 1998), h. 257

${ }^{22}$ Abd. al-Azizi Muhammad Azzam, Fiqh Muamalat, (Beirut: Dar al-Hadits, tt), h. 270 
Terdapat dalil yang menunjukkan bahwa orang yang menemukan barang tersebut wajib mengenal ciri-cirinya. Sehingga bila pemiliknya datang dan menjelaskan ciri-ciri yang sesuai dengan barang tersebut, dia bisa menyerahkan barang tersebut kepadanya. Bila ciri-ciri yang dia jelaskan berbeda dengan kenyataan, barang tersebut tidak boleh diserahkan kepadanya. ada sabda Nabi shallallahu 'alaihi wa sallam :

فإن لم تعرف؛ فاستنفقها

"Jika barang tersebut tidak ada yang mengakuinya, maka gunakanlah."

Terdapat dalil yang menunjukkan bahwa orang yang menemukan barang tersebut boleh memilikinya setelah satu tahun diumumkan. Tetapi dia tidak boleh menggunakannya sebelum mengenal ciri-cirinya. Maksudnya, sebelum dia hafal ciri-ciri wadah barang tersebut, tali pengikatnya, jumlah, dan jenis barang yang ada dalam wadah tersebut. Jika pemiliknya datang setelah satu tahun dan menjelaskan ciri-ciri yang sesuai dengan barang tersebut, maka dia serahkan barang tersebut kepadanya. Hal ini berdasarkan perkataan Nabi shallallahu 'alaihi wa sallam :

فإن جاء طالبها يوما من الدهر؛ فادفعها إليه "Jika pada suatu hari orang yang memintanya datang, maka hendaknya engkau berikan kepadanya."

\section{PENUTUP}

Dengan melihat dan merenungi aturan Islam terhadap barang temuan, difahamilah adanya perhatian dan penjagaan Islam terhadap harta, terkhusus terhadap kehormatan harta seorang muslim. Secara global, kita bisa memahami dari seluruh hal tersebut adanya anjuran di dalam Islam untuk tolong-menolong di atas kebaikan. Kita meminta kepada Allah subhanahu wa ta'ala agar mengokohkan kita semua di atas Islam dan mewafatkan kita dalam keadaan muslim.

Dalam pelaksanaan takhrij ini penulis menggunakan metode takhrij bi al-lafazh dengan menggunakan petunjuk kamus hadis al-Mu'jam ditemukan potongan matan hadis اعْرِنَ terdapat dalam; 1) al-Bukhari dalam Shahih-nya Kitab al-Ilm bab al-Ghadhab fi al-Maw'izhah wa alTa'lim No. 89. 2) Muslim dalam Shahihnya Kitab al-al-Luqthqh No. 3247, 3248, 3249, 3250. 3) al-Tirmidzi dalam Sunan-nya Kitab al-Ahkam No. 1293. 4) Abudawud dalam Sunan-nya Kitab al-Luqthqh, N0. 1451, 1452, 1453. 5) Ibnu Majah dalam Sunan-nya Kitab al-Ahkam, No. 2495. 6) Ahmad bin Hanbal dalam Musnad-nya Kitab Musnad al-Tsamiyyin, No. 16431, 20697. 7) Malik dalam al-Muatha' Kitab al-Iqdhiyah, No. 1248 
Bila ditelusri dengan lafazh وِكَاءَ ditemukan di dalam kitab al-Bukhari dalam Shahih-nya Kitab Luqathah, No hadis. 2199, 2150 dan kitab al-Thalaq No. hadis 4882, dan Ahmad bin Hanbal dalam Musnad-nya Kitab. Musnad al-Syamiyyin, No. 16422. Dari segi lambang-lambang periwayatan Hadis di atas tergolong $т и$ an an dan mu'anan, yang diperselisihkan tentang ketersambungan sanad-nya oleh para ulama hadis. Namun setelah dilakukan penelitian tentang kualitas pribadi para periwayatnya dan hubungan periwayat tersebut seluruh sanad-nya dinyatakan dalam keadaan bersambung (mutashil). Maka dapat ditarik kesimpulan bahwa sanad Hadis yang di-takhrij oleh Malik, hukumnya adalah Shahih dan dapat dijadika Hujjah 


\section{DAFTAR PUSTAKA}

Abd. al-Azizi Muhammad Azzam, Fiqh Muamalat, Beirut: Dar al-Hadits, tt

Abi Abdillah Muhammad bin Yazid al-Qazwinniy, Sunan Ibnu Majah, Juz.1, Bab,60 BeirutLebanon, Dar al-KOTOB al- ILMIYAH, 1998

Abi Abillah Muhammad bin Ismail, Shahih al-Bukhari, Semarang, Toha Putera, tt

Abu 'Isa al-Turmidzi, Sunan al-Tirmidziy, (Semarang, Karya Toha Putera, tt

Abu al-Husain Muslim Ibn al-Hajaj al-Imam al-Hafizh, Shahih Muslim, Bandung, Dahlan, tt

Ahmad bin Hanbal, Syarah Hamzah Ahmad Zain, Juz 9 al-Qahirah, Darul Hadits, tt

Burhan Bungin, Metodologi Penelitian Kualitatif, Jakarta: Raja Grafindo Persada, 2003

Ibnu Hajar al-Asqalani, Tahdzib al-Tahdzib, India, Majelis Dairah al-Ma'arif al-Nizamiyah, 1982

ohn Wensinck, Arnold, et al, Concordance et Indices De La Tradition Musulmane, diterjemahkan ke dalam Bahasa Arab oleh Muhammad Fu'ad 'Abd. al-Baqiy dengan judul al-Mu'jam al-Mufahras li Alfazh al-Hadis al-Nabawi, Leiden: E.J. Brill, 1967

Purwono,"Kajian Kepustakaan", dalam http://www.google.co.id Diakses 20 Juli, 2017

Sa'id al-Lahham dalam al-Muwaththa', , Beirut, Dar al-Ma'arif al-Nizamiyyah, 1983

Salahuddin bin Ahmad al-Adlab, Manhaj al-Naqd al-Mtn, Beirut, Dar al-Ma'arif al-Nizamiyyah, 1983

Sayyid Sabiq, Fiqih Sunnah 13, Pent. : Kamaluddin A. Marzuki, Bandung :PT. Al Ma’arif, 1987.

Shalih al-Fauzan, al-Mulakhas al-Fikhi, Madinah al-Munawarah: Salafiyah, 1998

Shiddiqiy Jamil al-'Atthar, al-Mu'attha’ Beirut Dar-al-KOTTOB, 2002

Shidqiy Muhammad Jamil, Sunan Abi Daud, Lil-Hafizh Abi Daud Sulaiman bin al-Asy 'ats alSajtani, Juz.1, Bab.65, Beirut-Lebanon, Dar-al-KOTTOB al-ILMIYAH,1998

Sulaiman Toha, Terjemahan Hadits Shahih Muslim, Jakarta : Pustaka al Husna, 1991.

Ulumul, Nawir Ilmu Hadis, Jakarta, PT Mutiaraa Sumber Widya, 2001 